\title{
ГОСУДАРСТВЕННЫЙ КОНТРОЛЬ В СФЕРЕ ЗАКУПОК: ОСНОВНЫЕ ПОЛОЖЕНИЯ И ОСОБЕННОСТИ
}

\author{
(c) 2020 Аверьянова Ольга Владимировна \\ преподаватель кафедры гуманитарных и социально-экономических дисциплин \\ Военно-медицинская Академия им. С. М. Кирова, Россия, Санкт-Петербург \\ Email:olin83@mail.ru
}

В соответствии с международной практикой сфера государственных закупок всегда находится под пристальным вниманием госорганов. Государственные закупки применяются не только как инструмент для поддержания государственной политики, но и как обеспечение отечественных нужд. Через данный инструмент можно влиять практически на всю экономическую политику государства.

Высокая специфичность отраслей контрактной системы в сфере государственных, муниципальных и корпоративных закупок обуславливает необходимость в развитии и адаптации государственного регулирования контрактных отношений, в том числе пересмотра модели контрольнонадзорной деятельности в сфере закупок и повышения грамотности всех участников контрактной системы страны.

Ключевые слова: контрактная система, государственные закупки, финансовое право, закупки, государственный контроль.

Государственное регулирование сферы государственных закупок является сложной многоуровневой системой, на каждом из этапов которой ведется строгий и бескомпромиссный контроль. Контроль в сфере государственных закупок в настоящее время нацелен на выявление злоупотреблений и нарушений законодательства о контрактной системе, в результате которого регулятор стремится добиться максимальной легитимности и прозрачности проводимых закупочных процедур за счет применения «палочной системы».

В условиях всеобщей цифровизации экономики большая часть контроля переведена в автоматический режим, который осуществляется за счет автоматизации процессов контроля информации документов, размещаемых заказчиками в единой информационной системе (далее ЕИС). Это способствует к снижению контрольных нагрузок, ложащихся на заказчиков и бизнес партнеров в рамках заключенных контрактов.

В целом контрольно-надзорной деятельности в сфере закупок присуща тенденция к снижению всех контрольных процедур за счет масштабирования процессов автоматизированного контроля.

Государственный контроль в сфере закупок Ф3 № 44 «О контрактной системе в сфере закупок товаров, работ, услуг для обеспечения госу- дарственных и муниципальных нужд » (далее ФЗ № 44) регулируется 99 статьей самого закона, контроль ФЗ № 223 «О закупках товаров, работ, услуг отдельными видами юридических лиц» (далее ФЗ № 223) регулируется законом «О конкуренции».

Законодательством о контрактной системе, а именно главой 5 Ф3 № 44, предусмотрены различные виды контроля, такие как:

- внутренний контроль;

- внешний контроль;

- внутриведомственный контроль;

- общественный и др.

Внутриведомственный контроль осуществляется в соответствии со ст. 100 ч. 5 ФЗ № 44 органами муниципальной власти, управлениями внебюджетных фондов, государственными органами и государственными корпорациями «Роскосмос» и «Росатом», осуществляющих ведомственный контроль за соблюдением законодательства РФ в сфере государственных закупок. Контроль ведется над подведомственными ими заказчиками с целью своевременного выявления и устранения нарушений, допускаемых в сфере государственных закупок.

Общественный контроль осуществляется в соответствии со ст. 102 ч. 5 Ф3 № 44 общественными объединениями и гражданами, которые вправе осуществлять контроль за соблюдением законодательства РФ. Согласно п. 3 данной ста- 
тьи общественные объединения вправе запрашивать у заказчика сведения об исполнении контракта, выступать с законодательной инициативой по изменению законодательства с целью его улучшения, а также при выявлении нарушений обращаться с соответствующим заявлением в суд, контролирующие и правоохранительные органы.

Согласно ст. 101 ч. 5 ФЗ № 44 регулятор обязал заказчиков осуществлять личный контроль за исполнением поставщиками условий контрактов.

Приведенные выше контрольные меры являются большей частью незначительными. Основными видами контроля являются внутренний и внешний.

Внутренний контроль осуществляют Федеральная антимонопольная служба и Федеральное казначейство России, тогда как внешний контроль осуществляет Счетная палата Российской Федерации.

По факту данные виды контроля большей частью схожи. Основным различием между ними, кроме как «терминологии» и субъектов контроля, является то, что внешний контроль осуществляется законодательной ветвью власти, а внутренний контроль осуществляется исполнительной ветвью власти.

- Федеральная антимонопольная служба, осуществляет контроль всей контрактной системы в целом и по ФЗ № 44, и по ФЗ № 223 в соответствии со статьями 99-102 Ф3 № 44;

- Счетная палата Российской Федерации, осуществляет аудит по ФЗ № 44 и ФЗ № 223, в соответствии с п. 2 ст. 98 Ф3 № 44;

- Федеральное казначейство России, осуществляет контроль в сфере закупок по ФЗ № 44 в рамках внутреннего государственного финансового контроля в соответствии с п. 1-3 ч. 8 ст. 99 ФЗ № 44 только на федеральном уровне.

Основным органом, осуществляющим контроль в ч. 8 ст. 99 ФЗ № 44 является Федеральное казначейство России, но оно осуществляет контроль лишь на федеральном уровне, региональный и муниципальный контроль осуществляют Комитеты государственного финансового контроля или отдельно созданные при Минфине отделы.

Муниципальный контроль осуществляют местные администрации. Необходимо заметить, что с начала 2019 г. Ф3 № 44 предусмотрена передача полномочий по муниципальному кон- тролю региональному органу контроля, что по нашему мнению отвечает всем современным требованиям к оптимизации государственного регулирования, так как муниципальный контроль как показывает практика является лишь фиктивным методом контроля. ФАС России осуществляет контроль в сфере государственных закупок и гособоронзаказа путем проведения плановых и внеплановых проверок (исключительно камеральным способом) по следующим, закрепленным в ч. 10 ст. 99 ФЗ № 44, вопросам:

- соблюдение заказчиками требований к обоснованию закупок;

- соблюдение заказчиками требований к нормированию в сфере закупок;

- соблюдение заказчиками требований к обоснованию и определению начальной максимальной цены контракта (далее НМЦК);

- соблюдение заказчиками требований к применению, предусмотренной законом, мер ответственности в случае нарушения исполнителями условий контрактов и договоров;

- соответствия поставленного (выполненного, оказанного) набора товаров, работ и услуг (далее ТРУ) условиям контракта;

- соответствия использования поставленного (выполненного, оказанного) ТРУ целям осуществления закупки;

- соблюдение всеми участниками контрактной системы закона «О защите конкуренции».

ФАС России - это контролирующий орган всей контрактной системы, который контролирует все закупки в целом и основной задачей которого является пресечение нарушения закона «О защите конкуренции». В случае выявления нарушений, орган направляет предписание об устранении нарушений, ведет административное делопроизводство, а также ведет инспекции по дисквалификации с рынка государственных закупок недобросовестных исполнителей на определенный срок.

Основные инструменты, которые применяет ФАС России в сфере контроля государственных закупок это камеральные проверки. По ФЗ № 44 ФАС России осуществляет два типа проверок:

- плановые проверки проводятся не чаще чем раз в три года. Перед началом нового финансового года составляется и публикуется план проверок, а позже публикуется в ЕИС сроком на полгода. Процесс проверки делится в 2 этапа, в том числе на рассмотрение документации и проведения заседания инспекции, на котором 
выносится решение о наличии или отсутствии нарушений. В случае обнаружения нарушений выдается протокол об административном правонарушении или направляется предписание устранить выявленные нарушения;

- внеплановые, проводятся неограниченное количество раз и основанием для начала внеплановой проверки является обращение участника закупок. Учитывая статистику, можно сделать вывод о том, что внеплановые проверки эффективнее, так как в ходе данных проверок чаще всего обнаруживаются нарушения и выносятся предписания как для исполнителя, так и для заказчика.

По ФЗ № 223 ФАС России осуществляет только один тип проверки - внеплановый, основанием для которой является обращения участников закупок, а также органов власти субъектов.

Гособоронзаказ является закрытой отраслью, по нему документы размещаются в закрытом контуре единой информационной системы (далее ЕИС), в котором есть допуск только у строго отведенных сотрудников ФАС, которые соответственно и осуществляют контроль в рамках таких закупок.

Счетная палата РФ - орган государственной власти, осуществляющий аудит по ФЗ № 44 и Ф3 № 223. Задачей, которого является оперативный анализ и подготовка отчетности путем осуществления плановых и внеплановых проверок на всех уровнях: федеральном, региональном и муниципальном, а также ревизия, обследование и мониторинг. Контрольно-счетная палата устанавливает причины найденных нарушений, занимается подготовкой предложений, которые направлены на устранение и совершенствование контрактной системы, размещением обобщенной информации о результатах аудита в ЕИС.

Основные положения контрольнонадзорной деятельности Счетной палаты РФ приведены в статье 97 ФЗ № 44 и в Федеральном законе от 05.04.2013 № 41-Ф3 «О Счетной палате РФ», согласно которым Счетная палата РФ в пределах, установленных за ним полномочий осуществляет оценку и анализ результатов закупок, мониторинг достижения заказчиками целей осуществления закупок. Для достижения целей контрольно-надзорной деятельности Счетная палата РФ как орган по аудиту в сфере закупок осуществляет информационную, экспертноаналитическую и иную деятельность посред- ством осуществления проверок, ревизий, анализа, оценки и обследования целесообразности, законности, обоснованности, результативности, эффективности и своевременности расходов на закупки государственных, муниципальных и корпоративных закупок, как на стадии планирования закупочного цикла, так и на стадии его реализации.

В ходе обобщения результатов осуществления своей деятельности Органы аудита в сфере закупок выводят причинно-следственную связь выявленных нарушений, недостатков и отклонений, подготавливают соответствующие предложения, нацеленные на их устранение и совершенствования контрактной системы, и представляют их в Государственную Думу.

С 1 июля 2019 года в части 2 статьи 99 Ф3 № 44 появились изменения. В настоящей редакции контроль проводится по новому регламенту, утвержденному Правительством РФ. На государственном уровне определяются предмет и форма проверок, критерии риска, порядок направления предписаний, перечень лиц, занимающихся проверками, а также порядок действий на тот случай, когда субъект не исполнил обязательства.

Наблюдается также улучшение в части 5 статьи 99 ФЗ № 44. С 1 ноября 2020 года статья дополнится и в ней будет говориться о том, что Казначейство с помощью автоматизированных информационных систем будет следить за соответствием внесенной в ЕИС информации, в том числе об ИКЗ, параллельно Контрольно-счетная палата проводит контроль и аудит по отношению к каждой закупке и согласовывает ее запись, что контроль, упомянутый в части 5 пройден.

Казначейство осуществляет мониторинг закупок совместно с Контрольно-счетной палатой, контролирует соответствие ИКЗ и другой информации о закупке, на превышение НМЦК лимитов бюджетных обязательств и другие сопроводительные контроли, в том числе правильность оформления реквизитов, соответствие уставной деятельности учреждения, наличие всей документации.

ФАС России является одним из основных регуляторов Ф3 № 44, его основные полномочия распространяются на контроль:

- за закупками для обеспечения государственных нужд;

- за закупками в рамках государственного оборонного заказа; 
- за операторами электронных площадок;

Контроль ведется преимущественно через работу с обращениями, а также посредством осуществления камеральных проверок.

В части государственного оборонного заказа контролирует обоснованность закупки и соблюдение ее требований, соблюдение правил нормирования, а также обоснование начальной максимальной цены контракта, соответствие поставленного товара с условиями контракта, а также применение мер ответственности к исполнителю в случае нарушения условий договоров.

Казначейство России является органом внутреннего государственного финансового контроля, и логично, что контроль за обоснованием и исполнением государственных программ, заданий и национальных проектов во всех сферах, основной статьей расходов по которым являются государственные закупки, должен включать контроль в сфере закупок ТРУ, для целей комплексного анализа расходования бюджетных средств.

Казначейство России осуществляет контроль в части 8 статьи 99 44-ФЗ посредством камеральных и выездных проверок. Также отвечает на обращения граждан в пределах своих полномочий, осуществляет плановую контрольную деятельность, а также внеплановые проверки.

Кроме того, Федеральное казначейство России также осуществляет контроль в сфере закупок: за обоснованием закупок, способа определения исполнителя и НМЦК, за соблюдением правил нормирования (в том числе предельных цен на ТРУ), применением к исполнителю мер ответственности при наличии фактов нарушений контрактов, за соответствием поставленного товара условиям контракта, а также за соответствием цели осуществления закупки (в том числе ее эксплуатацию по факту осмотра), правильностью ведения учета и оцифровывания необходимых документов и информации в ЕИС.

Так, комитеты государственного финансового контроля субъектов осуществляют такие же полномочия части 8 по контролю за расходованием субъектовых бюджетных средств, а муниципальные органы, такие как местные организации за муниципальными средствами.
Основным контрольным органом как для ФЗ № 223, так и для Ф3 № 44 является ФАС. Контроль за соблюдением требований ФЗ № 223 регулируется другим Федеральным законом это Ф3 № 135 «О защите конкуренции», который устанавливает жесткие рамки для заказчиков в части описания объекта закупки, так им запрещено указывать товарный знак, точные характеристики, которые сможет удовлетворить только один исполнитель или производитель и другие ограничения.

Данный фактор является деятельным инструментом государства за обеспечением рыночной добросовестной конкуренции в сфере закупок, однако наблюдаются частые жалобы заказчиков на то, что ограничение заказчиков в возможности описания объекта закупки посредством добавления более точных позиций дает возможность недобросовестным исполнителям цепляясь за установленные характеристики представлять товар, срок эксплуатации которого не соответствует желаемому.

Контроль за оцифровыванием и за соблюдением принципов открытости и гласности в рамках ФЗ № 223 осуществляет ФАС, однако Казначейство как оператор ЕИС осуществляет сопроводительный контроль за соблюдением всех форм и корректности заполнения документов и сведений в ЕИС.

Внутриведомственный контроль осуществляется специально созданными структурными подразделениями центральных аппаратов министерств, госкомпаний, учредителей, которые осуществляют внутренний контроль в целях предупреждения нарушений.

Так, внутренний контроль является одним из лучших способов контроля, так как он позволяет более безболезненно и адекватно проводить контроль и строить выводы, опираясь на знания специфики области и учреждения, в том числе в части взаимодействия с центральным аппаратом ведомства.

Внутриведомственный контроль осуществляется как посредством камеральных, так и выездных проверок. По результатам таких проверок, в случае обнаружения нарушений, они пересылаются в соответствующие уполномоченные органы для принятия соответствующих санкций. 


\section{Библиографический список}

1. Вилкин, А. С. Контроль размещения государственных и муниципальных заказов / А. С. Вилкин // Правовые вопросы в здравоохранении.-2012.-№ 3.- С. 92.

2. Федеральный закон «О размещении заказов на поставки товаров, выполнение работ, оказание услуг для государственных и муниципальных нужд» от 21.07.2005 N 94-Ф3 (утратил силу с 01.01. 2014 г.)

3. Федеральный закон «О контрактной системе в сфере закупок товаров, работ, услуг для обеспечения государственных и муниципальных нужд» от 05.04.2013 N 44-Ф3

4. Федеральный закон «О закупках товаров, работ, услуг отдельными видами юридических лиц» от 18.07 .2011 N 223-Ф3

5. Вершинина Е.С. Коррупционная составляющая государственных закупок // Молодой ученый.- 2015.№ 3.- С. 626-630. 